\title{
Front Matter: Volume 11631
}

, "Front Matter: Volume 11631," Proc. SPIE 11631, Advanced Biomedical and Clinical Diagnostic and Surgical Guidance Systems XIX, 1163101 (16 April 2021); doi: $10.1117 / 12.2596545$

SPIE. Event: SPIE BiOS, 2021, Online Only 


\section{Advanced Biomedical and Clinical Diagnostic and Surgical Guidance Systems XIX}

Caroline Boudoux

James W. Tunnell

Editors

6-11 March 2021

Online Only, United States

Sponsored and Published by

SPIE

Volume 11631 
The papers in this volume were part of the technical conference cited on the cover and title page. Papers were selected and subject to review by the editors and conference program committee. Some conference presentations may not be available for publication. Additional papers and presentation recordings may be available online in the SPIE Digital Library at SPIEDigitalLibrary.org.

The papers reflect the work and thoughts of the authors and are published herein as submitted. The publisher is not responsible for the validity of the information or for any outcomes resulting from reliance thereon.

Please use the following format to cite material from these proceedings:

Author(s), "Title of Paper," in Advanced Biomedical and Clinical Diagnostic and Surgical Guidance Systems XIX, edited by Caroline BoudouX, James W. Tunnell, Proceedings of SPIE Vol. 11631 (SPIE, Bellingham, WA, 2021) Seven-digit Article CID Number.

ISSN: 1605-7422

ISSN: 2410-9045 (electronic)

ISBN: 9781510640979

ISBN: 9781510640986 (electronic)

Published by

SPIE

P.O. Box 10, Bellingham, Washington 98227-0010 USA

Telephone +1 3606763290 (Pacific Time) · Fax +1 3606471445

SPIE.org

Copyright (c) 2021, Society of Photo-Optical Instrumentation Engineers.

Copying of material in this book for internal or personal use, or for the internal or personal use of specific clients, beyond the fair use provisions granted by the U.S. Copyright Law is authorized by SPIE subject to payment of copying fees. The Transactional Reporting Service base fee for this volume is $\$ 21.00$ per article (or portion thereof), which should be paid directly to the Copyright Clearance Center (CCC), 222 Rosewood Drive, Danvers, MA 01923. Payment may also be made electronically through CCC Online at copyright.com. Other copying for republication, resale, advertising or promotion, or any form of systematic or multiple reproduction of any material in this book is prohibited except with permission in writing from the publisher. The CCC fee code is $1605-$ $7422 / 21 / \$ 21.00$.

Printed in the United States of America by Curran Associates, Inc., under license from SPIE.

Publication of record for individual papers is online in the SPIE Digital Library.

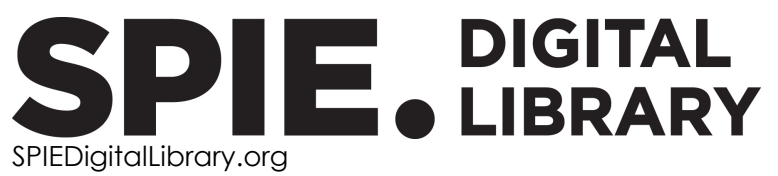

Paper Numbering: Proceedings of SPIE follow an e-First publication model. A unique citation identifier (CID) number is assigned to each article at the time of publication. Utilization of CIDs allows articles to be fully citable as soon as they are published online, and connects the same identifier to all online and print versions of the publication. SPIE uses a seven-digit CID article numbering system structured as follows:

- The first five digits correspond to the SPIE volume number.

- The last two digits indicate publication order within the volume using a Base 36 numbering system employing both numerals and letters. These two-number sets start with $00,01,02,03,04$, 05, 06, 07, 08, 09, 0A, OB ... 0Z, followed by 10-1Z, 20-2Z, etc. The CID Number appears on each page of the manuscript. 


\section{Contents}

\section{SPECTROSCOPY I}

$1163104 \quad$ Human brain meningioma tumor detection using visible resonance Raman spectroscopy [11631-2]

\section{SPECTROSCOPY II}

$116310 \mathrm{~A}$ Variations in oxygenation flow patterns from breath hold paradigm as a potential biomarker in differentiating normal to diseased tissues (TR) [11631-8]

\section{SURGICAL GUIDANCE}

$116310 D \quad$ Non-invasive enhanced mid-IR imaging for real-time surgical guidance [11631-11]

\section{ML/IMAGE PROCESSING}

$116310 N$ Intraoperative margin assessment in head and neck cancer using label-free fluorescence lifetime imaging, machine learning and visualization [11631-21]

IMAGING

$116310 Q \quad$ Investigating the effects of compressional and elastic photoacoustic waves to predict transcranial photoacoustic image quality for guidance of minimally invasive neurosurgeries [11631-24]

$116310 R \quad$ Design of a system combining narrow band illuminants and a color camera for early diagnosis of skin flap necrosis [11631-25]

11631 OS Motion picture acquisition and analysis of microcirculation in septic model rats [11631-26]

\section{FLUORESCENCE}

11631 От Intraoperative micrometastases detection using paired-agent fluorescent imaging: trial-anderror protocol development [11631-27] 
11631 OY Towards SFDI endoscopy with structured illumination from randomized speckle patterns [1 1631-32]

$1163110 \quad$ Electrosurgical knife equipped with diffused reflectance spectroscopy sensing for tumor margin detection during breast conserving surgery: a phantom study [11631-34]

$1163111 \quad$ Characterization of laser microbiopsy for sub-microliter tissue sampling [11631-35]

1163112 Fiber-optic based shape reconstruction of the medical needle for minimally invasive surgeries [1 1631-36]

\section{POSTER SESSION}

1163113 Augmented reality support system for endoscopic surgery using spectral reflectance estimation [11631-37]

1163114 Precise guiding and visualization of balloon catheter using photoacoustic imaging [11631-38]

1163115 Blind-deconvolution optical-resolution photoacoustic microscopy for high-resolution imaging of compact capillary [11631-39] 